\title{
KEMAMPUAN MENULIS RANGKUMAN TEKS LAPORAN HASIL OBSERVASI SISWA KELAS VII SMP NEGERI 49 KONAWE SELATAN
}

\author{
Grace Debora ${ }^{1}$,Haerun Ana ${ }^{2}$,dan La Ode Syukur ${ }^{3}$ \\ pbsi.fkip.uho@gmail.com
}

\author{
1,2,3, JurusanPendidikanBahasadanSastra Indonesia, \\ FakultasKeguruandanIlmuPendidikan, UniversitasHalu Oleo \\ KampusHijauBumiTridharmaAnduonohu, Kendari, Indonesia
}

\begin{abstract}
Abstrak
Tujuan dalam penelitian ini adalah untuk mengetahui kemampuan menulis rangkuman teks laporan hasil observasi siswa kelas VII SMP Negeri 49 Konawe Selatan. Metode yang digunakan dalam penelitian ini adalah metode deskriptif kuantitatif. Jenis penelitian ini tergolong dalam penelitian lapangan. Adapun teknik pengambilan sampel dengan menggunakan total sampling yaitu sebanyak 68 orang siswa yang terdiri atas tiga kelas. Instrumen yang digunakan dalam peneliti ini adalah esai tes siswa menulis rangkuman teks laporan hasil observasi. Untuk mengetahui kategori kemampuan menulis rangkuman teks laporan hasil observasi mengacu pada standar ketuntasan belajar individual dan klasikal yang digunakan di SMP Negeri 49 Konawe Selatan.Berdasarkan hasil penelitian menunjukkan bahwa dari 68 orang siswa yang menjadi sampel penelitian ini terdapat 56 orang siswa atau $82,35 \%$ mampu dalam menulis rangkuman teks laporan hasil observasi dan 12 orang siswa atau 17,64\% tidak mampu dalam menulis rangkuman teks laporan hasil observasi. Secaraklasikaldikatakantidakmampukarenasiswa yang mencapaikemampuan individual $\geq 70 \%$ hanyamencapai $80,88 \%$ tidakmencapaikriteriaketuntasanklasikal $85 \%$. Dilihat dari setiap aspek penilaian menulis rangkuman teks laporan hasil observasi yaitu kemampuan penulisan pernyataan umum memperoleh persentase sebesar $64,70 \%$ (tidak mampu), kemampuan penulisan deskripsi bagian memperoleh persentase sebesar $52,94 \%$ (tidak mampu), kemampuan penulisan deskripsi manfaat memperoleh persentase $27,94 \%$ (tidak mampu), penulisan majasrepetisimemperoleh persentase sebesar $89,70 \%$ (mampu), kemampuan penulisan kata gantimemperoleh persentase sebesar 55,88\% (tidak mampu), kemampuan penulisan kata hubung memperoleh persentase sebesar $100 \%$ (mampu), dan kemampuan penulisan kata kopula memperoleh persentase $88,23 \%$ (mampu).
\end{abstract}

Kata kunci: kemampuan; menulis; rangkuman; teks laporan hasil observasi

174 | Jurnal BASTRA (BahasadanSastra), Vol. 5 No.2, Edisi April 2020/e-ISSN: 25033875 /http://ojs.ohu.ac.id/index.php/BAS 


\begin{abstract}
The purpose of this study was to determine the ability to write text summary reports on the observation results of seventh grade students of SMP Negeri 49 Konawe Selatan. The method used in this research is quantitative descriptive method. This type of research belongs to field research. The sampling technique used a total sampling of 68 students consisting of three classes. The instrument used in this study was a student test essay writing a text summary of the observation report. To determine the category of ability to write text summary reports on the results of observations refers to the individual and classical learning completeness standards used in SMP Negeri 49 Konawe Selatan. Based on the results of the study showed that of the 68 students who were the samples of this study, 56 students or $82.35 \%$ were able to write a text summary of the observation report and 12 students or $17.64 \%$ were unable to write a text summary of the observation report. Classically it is said to be unable because students who achieve individual ability $\geq 70 \%$ only reach $80.88 \%$ do not reach the $85 \%$ classical completeness criteria. Judging from every aspect of the assessment of writing a summary of the observation report text, namely the ability to write general statements obtained a percentage of $64.70 \%$ (unable), the ability to write section descriptions obtained a percentage of 52.94\% (unable), the ability to write a description of the benefits obtained a percentage $27.94 \%$ (unable), repetitive figure writing got a percentage of $89.70 \%$ (capable), the ability to write pronouns got a percentage of $55.88 \%$ (unable), the ability to write conjunctions got a percentage of $100 \%$ (able), and the ability to write copula words obtained a percentage of $88.23 \%$ (capable).
\end{abstract}

Keywords: ability; writing; summary; observation report text

175| Jurnal BASTRA (BahasadanSastra), Vol. 5 No.2, Edisi April 2020/e-ISSN: 25033875 /http://ojs.ohu.ac.id/index.php/BAS 


\section{PENDAHULUAN}

Menulismerupakansalahsatuketer ampilanberbahasadalampembelajaranba hasa

Indonesia.Sebagaisuatuketerampilanber bahasa, menulismerupakankegiatan yang kompleks, karenapenulisdituntutuntukdapatmeny usundanmengorganisasikanisitulisanny asertamenuangkannyadalamformulasira gambahasatulisdankonvensipenulisanla innya.Di balikkerumitannya, menulismengandungbanyakmanfaatbag ipengembangan mental, intelektual, dansosialseseorang.Menulisdapatmenin gkatkankecerdasan,

mengembangkandayainisiatifdankreativ itas, menumbuhkankeberanian, sertameransangkemauandankemampua nmengumpulkaninformasi.

Kegiatan menulis sangat penting dalam pendidikan karena dapat membantu siswa berlatih berpikir, mengungkapkan gagasan, dan memecahkan masalah. Dengan menulis, seorang siswa mampu mengkonstruk berbagai ilmu atau pengetahuan yang di miliki dalam sebuah tulisan, baik dalam bentuk esai, artikel, laporan ilmiah, cerpen, puisi, dan sebagainya.

Mata pelajaran Bahasa Indonesia merupakan mata pelajaran wajib di SMP yang berfungsi sebagai alat pengembangan diri siswa dalam bidang ilmu pengetahuan, teknologi, seni dan budaya. Dengan demikian, dengan menguasai bahasa diharapkan siswa dapat tumbuh dan berkembang menjadi warga negara yang cerdas dalam pembangunan nasional.

Pembelajaran bahasa Indonesia meliputi empat keterampilan berbahasa, yaitu keterampilan menyimak, keterampilan berbicara, keterampilan membaca, dan keterampilan menulis. Keempat keterampilan tersebut masingmasing memliki fungsi yang berbeda. Untuk komunikasi secara lisan orang menggunakan keterampilan menyimak dan berbicara, sedangkan dalam komunikasi secara tertulis orang memanfaatkan keterampilan membaca dan menulis.

Keterampilan menulis adalah keterampilan yang paling kompleks, karena keterampilan menulis merupakan suatu proses perkembangan yang menuntut pengalaman, waktu, kesepakatan, latihan serta memerlukan cara berpikir yang teratur untuk mengungkapkannya dalam bentuk bahasa tulis. Kegiatan pembelajaran, akan bisa berjalan dengan lancar, kondusif, interaktif, apabila dilandasi oleh dasar kurikulum yang baik dan benar.

$$
\text { Kurikulum } 2013 \text { adalah }
$$
kurikulum yang mengarahkan proses pembelajaran harus bisa mendorong peserta didik untuk mengamati (observing), bertanya (questioning), menalar (associating), mencoba (experimenting), dan membentuk jejaring (networking). Untuk memenuhi prasyarat itu maka cara pembelajarannya tentu harus holistik dan meyenangkan. Pembelajaran

\section{6| Jurnal BASTRA (BahasadanSastra), Vol. 5 No.2, Edisi April 2020/e-ISSN: 25033875 /http://ojs.ohu.ac.id/index.php/BAS}


seyoganya menekankan aspek sikap, pengetahuan, dan keterampilan secara terintegrasi.

Proses pembelajaran sepenuhnya diarahkan pada pengembangan ketiga ranah tersebut secara utuh/holistik, artinya pengembangan ranah tersebut secara yang satu tidak bisa dipisahkan dengan ranah lainnya. Dengan demikian, proses pembelajaran secara utuh melahirkan kualitas pribadi yang mencerminkan keutuhan penguasaan sikap, pengetahuan, dan keterampilan yang dinilai autentik dan berbasis tes dan portofolio (saling melengkapi).

Pembelajaran bahasa Indonesia di sekolah menengah pertama (SMP) yang salah satunya penulisan rangkuman laporan observasi merupakan kemampuan yang harus dilakukan oleh para siswa karena menjadi salah satu target kemampuan yang harus dimiliki oleh para siswa yang tercantum dalam kurikulum 2013 yang telah dijabarkan dalam kompetensi inti, kompetensi dasar, dan indikator. Sesuai dengan Kompetensi Dasar, yakni siswa diharapkan "Mampu Menyajikan rangkuman teks laporan hasil observasi yang berupa buku pengetahuan secara lisan dan tulis dengan memperhatikan kaidah kebahasaan atau aspek lisan". Sesuai dengan kompetensi dasar siswa diharapkan mampu menulis rangkuman teks laporan hasil observasi dengan memperhatikan struktur laporan hasil observasi dan kaidah kebahasaan. Oleh karena itu, seluruh siswa ikut serta melibatkan diri dalam tiga kegiatan yang diselenggarakan di sekolah. Jadi guru perlu memetakan setiap setiap KD, terhadap KI yang bersesuaian. Ketika hendak mengajar, perlu diperhatikan apa yang harus dicapai oleh siswa. Melalui kegiatan tersebut, siswa dapat memiliki pengalaman yang bermanfaat.

Dalam proses menulis rangkuman laporan hasil observasi sangat diperlukan keantusiasan siswa karena siswa diajak untuk berpikir dari hasil bacaan dan membuat rangkuman menjadi teks laporan hasil observasi yang ada pada buku siswa kelas VII SMP. Salah satu keterampilan yang harus dikuasai oleh siswa kelas VII dalam kurikulum 2013 adalah siswa mampu menulis rangkuman teks laporan hasil observasi. Dalam menulis rangkuman teks laporan hasil observasi siswa diharapkan mampu memahami tentang bagaimana menulis rangkuman teks laporan hasil observasi dengan penulisan judul, struktur pembentukannya yang terdiri atas definisi umum, deskripsi bagian, deskripsi manfaat, dan simpulan. Dalam menyusun rangkuman teks laporan hasil observasi, siswa harus membaca dan memahami makna teks serta merangkum sehingga dapat menyajikan ulang dengan bahasa sendiri yang ada pada teks.

Peneliti memilih kemampuan menulis rangkuman teks laporan hasil observasi karena tertuang dalam kurikulum 2013, buku bahasa Indonesia kelas VII SMP/MTs yang terdapat pada semester satu, dengan kompentensi dasar menyajikan rangkuman teks laporan hasil observasi yang berupa buku pengetahuan secara lisan dan tulis dengan memperhatikan kaidah kebahasaan atau aspek lisan. Sebagai tempat penelitian didasari atas pertimbangan, siswa kelas VII SMP Negeri 49 Konawe Selatan telah 
mempelajari menulis rangkuman teks laporan hasil observasi sesuai dengan kurikulum yang berlaku dan rasa keingintahuan peneliti untuk mengetahui tingkat penguasaan siswa yang masih baru mengalami peralihan dari masa sekolah dasar ke jenjang sekolah lanjutan tingkat menengah pertama terhadap menulis rangkuman teks laporan hasil observasi yang ditulis oleh siswa. Dari hasil observasi yang dilakukan, tujuan penilitian ini yaitu untuk mengukur tingkat keberhasilan siswa dengan KKM yang telah ditentukan di SMP Negeri 49 Konawe Selatan dan untuk mengetahui kemampuan siswa dalam menulis rangkuman teks laporan hasil observasi. Disediakan sebuah teks laporan hasil observasi dan kemudian siswa menulis rangkuman dari teks tersebut.

Berdasarkan uraian diatas, peneliti tertarik untuk meneliti kemampuan menulis rangkuman teks laporan hasil observasi siswa kelas VII SMP Negeri 49 Konawe Selatan.

Berdasarkan latar belakang yang telah diuraikan sebelumnya, yang menjadi masalah dalam penelitian ini adalah bagaimanakah kemampuan menulisrangkumantekslaporanhasilobse rvasipadasiswakelas VII SMP Negeri 49 Konawe Selatan?

Tujuan dari penelitian ini adalah untuk mendeskripsikan kemampuansiswa kelas VII SMP Negeri 49 Konawe Selatan dalammenulisrangkumantekslaporanha silobservasi.

Sesuai dengan tujuan yang telah di kemukakan di atas, maka manfaat yang di harapkan dari hasil penelitian ini adalah: a. Memperoleh deskripsi secara jelas mengenai kemampuan siswa kelas VII SMP Negeri 49 Konawe Selatan dalammenulistekslaporanhasilobser asi. Dan sebagaidasaruntuklebihmeningkatp restasibelajarBahasa Indonesia, utamanya yang berkaitandengankemampuantekslap oranhasilobservasi.

b. Sebagaibahaninformasibagi guru Bahasa Indonesia di SMP Negeri 49 Konawe Selatan agar lebihmengoptimalkankegiatanpemb elajaranBahasa Indonesia, khususnyaaspekpembelajaranmenul istekslaporanhasilobservasibaiksegi perencanaan, pembelajaran, danpengevaluasinya.

c. Sebagaiinformasitambahanbagipene litidanpenelitipenelitiselanjutnyauntuk di jadikanrujukanpenelitian yang relevan.

\section{METODE DAN TEKNIK}

Metode yang digunakan dalam penelitian ini adalah metode deskriptif kuantitatif. Deskriptif yaitu mendiskripsikan data penelitian secara obyektif tentang kemampuan menulis teks laporan hasil observasi siswa kelas VII SMP Negeri 49 Konawe Selatan, sedangkan kuantitatif maksudnya adalah data yang terkumpul diolah dengan menggunakan rumus statistik.

Penelitian ini berdasarkan pada jenisnya merupakan penelitian lapangan, karena peneliti turun ke sekolah tempat sampel untuk mengumpulkan data sesuai dengan masalah dalam penelitian ini.

\section{8| Jurnal BASTRA (BahasadanSastra), Vol. 5 No.2, Edisi April 2020/e-ISSN:}

\section{5 /http://ojs.ohu.ac.id/index.php/BAS}


Populasi dalam penelitian ini adalah seluruh siswa kelas VII SMP Negeri 49 Konawe Selatan yang terdaftar pada tahun pelajaran 2018/2019 dengan jumlah 68 orang. Berdasarkan data dari SMP Negeri 49 Konawe Selatan, jumlah siswa tersebut tersebar dalam tiga kelas yaitu kelas VIIA $=22$ orang, VIIB $=23$ orang, VIIC = 23 orang. Populasi siswa bersifat heterogen dalam arti bahwa siswa memiliki kemampuan yang berbedabeda dalam menerima pelajaran.

Ada beberapa rumus yang dapat digunakan oleh peniliti untuk menentukan jumlah anggota sampel. Untuk sekedar ancer-ancer, apabila subjeknya kurang dari 100, lebih baik diambil semua sehingga penelitiannya merupakan penelitian populasi (Arikunto, 2002: 12). Dengan demikian, sampel yang diambil dalam penelitian yaitu kurang dari 100, maka sampel dalam penelitian ini berjumlah 68 orang.

Penelitian ini menggunakan instrumen tes tertulis yang berbentuk esai yaitu kemampuan menulis rangkuman teks laporan hasil observasi dengan membaca teks yang sudah disediakan dengan memperhatikan struktur dan kaidah kebahasaan teks laporan hasil observasi.

Teknik pengumpulan data dalam penelitian ini adalah tes esai. Langkahlangkah yang digunakan untuk memperoleh data pada tes kemampuan menulis rangkuman teks laporan hasil observasi adalah sebagai berikut.

1. Mengecek kehadiran siswa.

2. Membagi lembar tugas, berfungsi sebagai alat pengumpul data dan digunakan untuk menulis rangkuman teks laporan hasil observasi.

3. Masing-masing siswa menulis rangkuman teks laporan hasil observasi dalam waktu 80 menit.

4. Hasil menulis rangkuman teks laporan hasil observasi siswa dikumpulkan secara kolektif.

5. Memberikan penilaian penulisan laporan hasil observasi siswa dengan aspek yang telah ditentukan.

Penilaian penulisan teks laporan hasil observasi dengan memperhatikan aspek sebagai berikut: pernyataan umum, deskripsi bagian, deskripsi manfaat, repetisi, kata ganti, kata hubung, kata kopula.

Analisis data dilakukan denganteknikpersentasedenganmenggu nakanangka-angka.

Teknikpersentasedilakukanuntukmenge tahuikemampuansiswadalammenulisra ngkumantekslaporanobservasi. Tingkat kemampuanmenulisrangkumantekslapo ranobservasimengacupadakemampuany aituanggapanbahwasecara individual maupunklasikaldikatakanmampuapabil adapatmenguasai minimal $70 \%$ dariaspek yang dinilaisecara individual, sedangkanklasikaldikatakanmampuapa biladapatmenguasai $\quad 85 \%$ dariaspek yang dinilaisecaraklasikal. Standarkelulusanatausiswadikatakanma mpuapabilasiswamemperolehstandar KKM nilai 70.

Dari persentase yang diperoleh,baik untuk kemampuan siswa secara individual maupun secara klasikal selanjutnya diacukan pada penilaian yang telah ditetapkan untuk menentukan kemampuan siswa. Untuk lebih jelasnya,berikut tabel penilaian ketuntasan.

\section{9| Jurnal BASTRA (BahasadanSastra), Vol. 5 No.2, Edisi April 2020/e-ISSN:}

25033875 /http://ojs.ohu.ac.id/index.php/BAS 
Tabel2.1 Rentang Kemampuan Siswa

\begin{tabular}{|c|c|c|}
\hline $\begin{array}{l}\text { Kategori } \\
\text { kemampuan }\end{array}$ & $\begin{array}{l}\text { Rentang } \\
\text { skor }\end{array}$ & $\begin{array}{l}\text { Persentase } \\
\text { kemampuan( } \\
\%)\end{array}$ \\
\hline Mampu & 24-34 & $70 \%-100 \%$ \\
\hline $\begin{array}{c}\text { Tidak } \\
\text { Mampu }\end{array}$ & $1-23$ & $2 \%-67 \%$ \\
\hline
\end{tabular}

49 Konawe Selatan Kelas VII

Berdasarkan analisis persentase diatas, dapat dikatakan bahwa dari 7 aspek yang diukur yaitu kemampuan menulis pernyataan umum, kemampuan menulis deskripsi bagian, kemampuan menulis deskripsi manfaat, kemampuan menulis penulisan majas repetisi, penulisan kata ganti, penulisan kata hubung, dan penulisan kata kopula pada setiap aspek menunjukan persentase yang berbeda. Untuk lebih jelasnya dapat dilihat pada tabel berikut.

Tabel 2.2 Rangkuman Data

\begin{tabular}{ccc}
\hline $\begin{array}{c}\text { Aspek } \\
\text { Penilaian }\end{array}$ & $\begin{array}{c}\text { Tingkat } \\
\text { Kemampuan }\end{array}$ & Kategori \\
\hline $\begin{array}{c}\text { Pernyataan } \\
\text { Umum }\end{array}$ & $80,88 \%$ & $\begin{array}{c}\text { Tidak } \\
\text { Mampu }\end{array}$ \\
\hline $\begin{array}{c}\text { Deskripsi } \\
\text { Bagian }\end{array}$ & $64,70 \%$ & $\begin{array}{c}\text { Tidak } \\
\text { Mampu }\end{array}$ \\
\hline $\begin{array}{c}\text { Deskripsi } \\
\text { Manfaat }\end{array}$ & $27,94 \%$ & $\begin{array}{c}\text { Tidak } \\
\text { Mampu }\end{array}$ \\
\hline $\begin{array}{c}\text { Majas } \\
\text { Repetisi }\end{array}$ & $89,70 \%$ & Mampu \\
\hline Kata Ganti & $55,88 \%$ & $\begin{array}{c}\text { Tidak } \\
\text { Mampu }\end{array}$ \\
\hline $\begin{array}{c}\text { Kata } \\
\text { Hubung }\end{array}$ & $100 \%$ & Mampu \\
\hline Kata Kopula & $88,23 \%$ & Mampu \\
\hline \multicolumn{3}{c}{ Berdasarkan tabel di atas, maka } \\
kemampuan menulis rangkuman teks \\
laporan hasil observasi siswa kelas VII \\
SMP Negeri 49 Konawe Selatan, dilihat
\end{tabular}

dari seluruh aspek dapat dideskripsikan sebagai berikut.

1. Kemampuanmenulisrangkumanteks laporanhasilobservasipadaaspekper nyataanumumsecaraklasikaldikateg orikantidakmampu.

Dikatakantidakmampukarenasiswa yang secara individual mencapaikemampuan $\quad 70 \%$ hanyasebesar $\quad 64,70 \%$. Hal initidakmencapaikriteriaketuntasan klasikalyaitu $85 \%$.

2. Kemampuanmenulisrangkumanteks laporanhasilobservasipadaaspekdes kripsibagiansecaraklasikaldikategori kantidakmampu.

Dikatakantidakmampukarenasiswa yang secara individual mencapaikemampuan $\quad 70 \%$ hanyasebesar 52,94\%. Hal initidakmencapaikriteriaketuntasan klasikalyaitu $85 \%$.

3. Kemampuanmenulisrangkumanteks laporanhasilobservasipadaaspekdes kripsimanfaatsecaraklasikaldikatego rikantidakmampu.

Dikatakantidakmampukarenasiswa yang secara individual mencapaikemampuan $\quad 70 \%$ hanyasebesar 27,94\%. Hal initidakmencapaikriteriaketuntasan klasikalyaitu $85 \%$.

4. Kemampuanmenulisrangkumanteks laporanhasilobservasipadaaspek penulisanmajasrepetisisecaraklasikal dikategorikanmampu.

Dikatakanmampukarenamencapai $70 \%$ yaitu $89,70 \%$, yaknitelahmencapaikriteriaketuntas anklasikal 85\%.

5. Kemampuanmenulisrangkumanteks laporanhasilobservasipadaaspekpen ulisan kata

180| Jurnal BASTRA (BahasadanSastra), Vol. 5 No.2, Edisi April 2020/e-ISSN: 25033875 /http://ojs.ohu.ac.id/index.php/BAS 
gantisecaraklasikaldikategorikantida kmampu.

Dikatakantidakmampukarenasiswa yang secara individual mencapaikemampuan $\quad 70 \%$ hanyasebesar 55,88\%. Hal initidakmencapaikriteriaketuntasan klasikalyaitu 85\%.

6. Kemampuanmenulisrangkumanteks laporanhasilobservasipadaaspekpen ulisan kata hubungsecaraklasikaldikategorikan mampu.

Dikatakanmampukarenamencapai $70 \%$ yaitu 100\%, yaknitelahmencapaikriteriaketuntas anklasikal 85\%.

7. Kemampuanmenulisrangkumanteks laporanhasilobservasipadaaspekpen ulisan kata kopulasecaraklasikaldikategorikanm ampu.

Dikatakanmampukarenamencapai $70 \%$ yaitu 88,23\%, yaknitelahmencapaikriteriaketuntas anklasikal 85\%.

Berdasarkan hasil tersebut dan analisis data secara klasikal dapat diketahui bahwa secara keseluruhan (klasikal) kemampuan menulis rangkuman teks laporan hasil observasi siswa kelas VII SMP Negeri 49 Konawe Selatan adalah tidak mampu dengan persentase kemampuan $80 \%$.

\section{KESIMPULAN}

Berdasarkan hasil penelitian data yang dilakukan, dapat disimpulkan bahwa dari 68 orang siswa kelas VII SMP Negeri 49 Konawe Selatan, terdapat 55 orang siswa $(80,88 \%)$ masuk kategori mampu secara individual dalam menulis rangkuman teks laporan hasil observasi, dan sebanyak 13 orang siswa $(19,11 \%)$ masuk kategori tidak mampu dalam menulis rangkuman teks laporan hasil observasi. Secara klasikal dapat dikatakan bahwa kemampuan siswa kelas VII SMP Negeri 49 Konawe Selatan dalam menulis rangkuman teks laporan hasil observasi masuk kategori tidak mampu secara klasikal. Dikatakan demikian karena kemampuan siswa hanya mencapai $80,88 \%$ belum mencapai kriteria ketuntasan klasikal yaitu $85 \%$. Jika dilihat dari setiap aspek penilaian kemampuan siswa kelas VII SMP Negeri 49 Konawe Selatan dapat disimpulkan bahwa dari ketujuh aspek yang menjadi aspek penilaian yaitu pernyataan umum, deskripsi bagian, repetisi, kata ganti, kata hubung, kata kopula, terdapat tiga aspek mampu mencapai ketuntasan klasikal, yaitu penggunaan majas repetisi (89\%), penggunaan kata hubung (100\%), dan penggunaan kata kopula (88\%). Sedangkan empat aspek tidak mampu mencapai ketuntasan klasikal, yaitu pernyataan umum (64\%), deskripsi bagian (52\%), deskripsi manfaat (27\%), dan penggunaan kata ganti (55\%).

\subsection{Saran}

Dengan mengacu pada kemampuan siswa yang diperhatikan dalam menulis rangkuman teks laporan hasil observasi dalam penelitian disarankan sebagai berikut. Berdasarkan hasil penelitian ini penulis memberikan saran sebagai berikut.

a. Guru bahasa Indonesia sebaiknya lebih kreatif dalam pembelajaran bahasa Indonesia dalam memilih teks laporan hasil observasi agar siswa tertarik untuk mengikuti pembelajaran khususnya tentang 
menulis rangkuman teks laporan hasil observasi.

b. Guru bahasa Indonesia perlu memberikan perhatian khususnya kepada siswa yang belum memiliki kemampuan dalam menulis rangkuman teks laporan hasil observasi.

c. Untuk pembelajaran menulis rangkuman teks laporan hasil observasi, guru dapat menyesuaikan ketuntasan materi pembelajaran dengan pemahaman siswa sehingga keseluruhan aspek-aspek dalam menulis rangkuman teks laporan hasil observasi dapat dipahami oleh siswa.

d. Dalam proses pembelajaran sebaiknya perlu dilakukan pemberian latihan-latihan.

\section{DAFTAR PUSTAKA}

Abigail, W. Monica. 2015. BelajarMenulis. Surabaya: JP Books.

Achmad, Sri Wintala.2015 .Buku Induk Mahir Bahasa dan Sastra Indonesia:Pedoman Praktis Menulis dalam Bahasa Indonesia. Yogyakarta: Araskia.

Aryani, HevianaSepti. 2015. PanduanBukuMajas EYD Peribahasa Kata Baku ETidak Baku. Yogyakarta: BukuPintar.

Arikunto, Suharsimi. 2002. ProsedurPenelitianSuatuPendekatan $\mathrm{Pr}$ aktek. Jakarta: PT RinekaCipta.

Dalman. 2016. Keterampilan Menulis. Jakarta: Rajawali Pers.

Hasriati, Titik, dkk. 2017. Buku Guru Bahasa Indonesia Revisi 2017. Jakarat: PusatKurikulum dan Prbukuan, Balitbang, Kemendikbud.

Harsiati, Titik, dkk. 2017. Bahasa Indonesia Revisi 2017. Jakarta: PusatKurikulum dan Prbukuan, Balitbang, Kemendikbud.

Jabrohim, Dkk. 2009.Cara MenulisKreatif. Yogyakarta: PustakaPelajar Offset.

Mahsun. 2014. Teks dalam Pembelajaran Bahasa Indonesia Kurikulum 2013. Jakarta: Rajawali Pers.

Mariani, Ani. 2010. Guru Bahasa Indonesia HarusBisaMenulis. Jakarta: PusatBahasa.

Mulyadi, Yadi, dkk. 2018. Bahasa Indonesia untuk Siswa SMP/MTs Kelas VII. Bandung: Yrama Widya

Parera, Jos. Daniel. 1987. MenulisTertibdanSistematik. Jakarta: PenerbitErlangga.

Rosidi, Imron. 2009. Menulis... Siapa Takut?. Yogyakarta: Kanisisus.

182 I Jurnal BASTRA (BahasadanSastra), Vol. 5 No.2, Edisi April 2020/e-ISSN: 25033875 /http://ojs.ohu.ac.id/index.php/BAS 
Soebachman, Adiba A. 2016. Mahir Menulis dalam 4 Hari. Yogyakarta: KaunaPustaka.

Suparno dan Mohamad Yunus. 2008. Keterampilan Dasar Menulis. Jakarta: Universitas Terbuka.

Sutejo, Fairul Zabadi, dkk. 2014. Bahasa Indonesia Wahana Pengetahuan. Jakarta: Kementrian Pendidikan dan Kebudayaan.

Tarigan, Henry Guntur. 2013. Menulis Sebagai Suatu Keterampilan Berbahasa. Bandung: Angkasa. 